\title{
Effect of short-term ethanol on the proliferative response of Swiss 3T3 cells to mitogenic growth factors
}

\author{
Eui-Ju Yeo ${ }^{1,4}$, Hee Kyoung $\mathrm{Lim}^{2}$ and \\ Sang Chul Park ${ }^{3}$ \\ ${ }^{1}$ Department of Biochemistry and the Institute of Life Science, \\ Cheju National University College of Medicine, Cheju, Korea \\ ${ }^{2}$ Department of Biology, Cheju National University College of \\ Natural Science, Cheju, Korea \\ ${ }^{3}$ Department of Biochemistry, Seoul National University College of \\ Medicine, Seoul, Korea \\ ${ }^{4}$ Correspondening author: Tel, +82-64-754-3836; \\ Fax, +82-64-725-2593; E-mail, euijuyeo@ @cheju.cheju.ac.kr
}

Accepted 23 September 2000

Abbreviations: DMEM, Dulbecco's modified Eagles medium; EGF, epidermal growth factor; ERK, extracellular signal-regulated protein kinase; FBS, fetal bovine serum; JNK, c-Jun $\mathrm{NH}_{2}$-terminal protein kinase; MAPK, mitogen-activated protein kinase; MBP, myelin basic protein; PDGF, platelet-derived growth factor

\begin{abstract}
Both adaptive and deleterious responses of cells to ethanol are likely triggered by short-term interactions of the cells with ethanol. Many studies have demonstrated the direct effect of ethanol on growth factor-stimulated cell proliferation. Using Swiss 3T3 cells whose growth was inhibited by ethanol in a concentration-dependent manner, we further investigated the molecular mechanisms of acute ethanol treatment by examining its effect on EGF- and PDGF-mediated cellular signaling systems for the mitogenic function. Tyrosine autophosphorylation of the growth factor receptors was partially prevented by ethanol in intact cells. When ethanol was included before or after EGF stimulation, no effect on the receptor signaling was observed. Here we also report that ethanol inhibits activation of ERK induced by both EGF and PDGF. EGF-induced JNK activation was reduced but PDGF-induced rapid JNK activation was delayed by the addition of ethanol. The balance between its inhibitory and stimulatory effect on the signaling molecules might determine the rate of cell growth.
\end{abstract}

Keywords: Swiss $3 T 3$ fibroblast, ethanol, EGF, PDGF, ERK, JNK/SAPK

\author{
Introduction
}

Tissue injury by either acute or chronic exposure to ethanol is due to several factors including accumulation of acetaldehyde and modified proteins, alterations in cellular redox state, microsomal activation of toxins, deranged mitochondrial function, and the enhancement of lymphocyte cytotoxicity (Devi et al., 1993; Lieber, 1994; Arnon et al., 1995). In addition, ethanol also interferes with the proliferation of several diverse cell lines in vitro, including astrocytes, human $\mathrm{T}$ cells, and primary rat hepatocytes. The anti-proliferative effects of ethanol may contribute to the pathogenesis and progression of alcoholic diseases. Alcoholic liver disease is a direct result of impaired hepatic regenerative activity due to the inhibition of growth factor-stimulated DNA synthesis (Carter and Wands, 1985). A disruption of neuronal cell proliferation by ethanol has been shown to contribute to fetal alcohol syndrome (Guizzetti and Costa, 1996; Luo and Miller, 1997b, 1999).

Many studies have attempted to define the cellular and molecular mechanisms in the anti-proliferative actions of ethanol. The blockage of growth factor-mediated cell proliferation by ethanol in several systems elicits the hypothesis that growth factor-induced signaling processes are targets of ethanol toxicity. Included are adenylate cyclase (Hoek et al., 1992; Williams and Kelly, 1993), protein kinase C (Pandy, 1996), protein tyrosine kinases (Miyakawa et al., 1997, Resnicoff et al., 1993, Thurston and Shukla, 1992), MAPKs (Roivainen et al., 1995; Reddy and Shukla, 1996; Chen et al., 1998; Tombes et al., 1998; Reddy and Shukla, 2000), phospholipase C and D (Higashi and Hoek, 1991; Hoek et al., 1992; Thurston and Shukla, 1992; Saso et al., 1997; Zhang and Farrell, 1999), transcription factors such as NF-אB (Zeldin et al, 1996) and STAT3 (Chen et al., 1997).

However, ethanol is not a universal inhibitor of cell growth. The effect of ethanol on those signaling molecules varies according to the tissues and cell lines. Ethanol also showed different responses depending on the type of growth factors. The differing expression of growth factor receptors and proliferative responses to each growth factor might explain the differential sensitivity of cells to ethanol (Luo and Miller, 1997a). The effect of ethanol is also different depending on whether its action is acute or chronic, and the concentration of both ethanol itself and the growth factor(s). In an effort to define the site(s) of the ethanol action, we further investigated the mechanism by which acute ethanol modulates growth factor responses. 
Using Swiss 3T3 cells whose growth is inhibited by ethanol dose-dependently, we further studied the effect of ethanol on DNA synthesis and a cellular signal transduction system activated by two major mitogens, epidermal growth factor (EGF)- and platelet-derived growth factor (PDGF) by examining tyrosine phosphorylation of cellular proteins including the receptors for both PDGF and EGF which elicit many cellular responses via activation of intrinsic tyrosine kinase. To investigate the mechanism by which ethanol modulates growth factor responses, we also examined the activity of mitogen-activated protein kinases (MAPKs), including ERK and c-Jun $\mathrm{NH}_{2}$-terminal protein kinases (JNKs), also known as stress-activated protein kinases (SAPK), which play a pivotal role in various biological events including cell proliferation and differentiation.

\section{Materials and Methods}

\section{Materials}

An ECL detection kit, $\left[{ }^{3} \mathrm{H}\right]$ thymidine, and $\left[\gamma^{32} \mathrm{P}\right] \mathrm{ATP}$ were purchased from Amersham Life Science (Buckinghamshire, England); phenyl methylsulfonyl fluoride (PMSF), aprotinin, Dulbecco's modified Eagle's medium (DMEM), dithiothreitol (DTT), protein A agarose beads, myelin basic protein (MBP) from Sigma (St.Louis, MO, USA); paraformaldehyde from Merck (Darmstadt, Germany); benzamidine hydrochloride from Aldrich (Milwaukee, WI, USA); fetal bovine serum and antibiotics (penicillin and streptomycin) from Gibco/BRL Life Technologies, Inc. (Gaithersburg, MD, USA); Immobilon-P from Millipore (Bedford, MA, USA); horseradish peroxidase-conjugated anti-rabbit IgGs from Vector Laboratory (Burlingame, CA, USA); a BCA protein assay kit from Pierce (Rockford, IL, USA); polyclonal antibodies against phosphotyrosine, and CJun (1-169) GST-glutathione agarose conjugate from Upstate Biotechnology. EGF was from Calbiochem (San Diego, CA, USA); PDGF from Bohringer Mannheim.

\section{Cell Cultures}

Swiss 3 T3 cells were cultured in DMEM supplemented with $10 \%(\mathrm{v} / \mathrm{v})$ fetal bovine serum, 100 units of penicillin/ $\mathrm{ml}$, and $100 \mu \mathrm{g}$ of streptomycin $/ \mathrm{ml}$ at $37^{\circ} \mathrm{C}$ in a humidified, $\mathrm{CO}_{2}$-controlled $(5 \%)$ incubator. For all experiments, cells were grown on $10-\mathrm{cm}$ culture dishes to subconfluency (about $80-90 \%$ ).

\section{MTT Assay}

Swiss 3 T3 cells $\left(3 \times 10^{5}\right.$ cells $\left./ \mathrm{ml}\right)$ were grown on wells in a 24 well plate and treated with ethanol as described in the figure legend. Cells were washed with phosphatebuffered saline (PBS) once and one milliliter of 3-[4,5dimethylthiazol-2-yl]-2,5-diphenyl-tetrazolium bromide (MTT) solution (2 $\mathrm{mg} / \mathrm{ml}$ PBS) was added to each well. The plates were incubated at $37^{\circ} \mathrm{C}$ for $4 \mathrm{~h}$. After MTT solution was aspirated and cells were PBS-washed once, one $\mathrm{ml}$ of DMSO was added to dissolve the blue insoluble MTT formazan produced by mitochondrial succinate dehydrogenase. The optical density was measured at $570 \mathrm{~nm}$ using a spectrophotometer (Kontron Uvikon 930). The percentage of viable cells was calculated as the relative ratio of optical densities.

\section{DNA Synthesis}

Swiss 3 T 3 cells grown on 6 well plates were treated with mitogens in the presence or absence of ethanol for 16 $\mathrm{h}$ and labeled with $1 \mu \mathrm{Ci} / \mathrm{ml}$ of $\left[{ }^{3} \mathrm{H}\right]$ thymidine for $4 \mathrm{~h}$. Cells were then washed with ice-cold PBS twice and fixed with ice cold $10 \%$ TCA. After incubation for $30 \mathrm{~min}$ on ice, cells were washed once more with $10 \%$ TCA and diethylether/ethanol mixture $(1: 2)$. Plates were airdried and $0.75 \mathrm{ml}$ of $0.5 \mathrm{M} \mathrm{NaOH}$ to each well was added to dissolve DNA. One half millilitter of aliquots was neutralized by an aliquot of $6 \mathrm{~N} \mathrm{HCl}$ and the radioactivity was counted in $5 \mathrm{ml}$ of Ready Safe scintillation cocktail.

\section{Western Blot Analysis}

Cells were lysed in $2 \mathrm{ml}$ of lysis buffer $(50 \mathrm{mM}$ Tris- $\mathrm{HCl}$, pH 7.5, containing $150 \mathrm{mM} \mathrm{NaCl}, 2 \mathrm{mM}$ EDTA, $1 \mathrm{mM}$ EGTA, $1 \mathrm{mM} \mathrm{Na}_{3} \mathrm{VO}_{4}, 10 \mathrm{mM} \mathrm{NaF}, 1 \mathrm{mM}$ DTT, $1 \mathrm{mM}$ PMSF, $25 \mu \mathrm{g} / \mathrm{ml}$ leupeptin, $25 \mu \mathrm{g} / \mathrm{ml}$ aprotinin, $5 \mathrm{mM}$ benzamidine, and $1 \%$ Nonidet P-40) for $30 \mathrm{~min}$ on a rocker at $4^{\circ} \mathrm{C}$. The lysates were spun at $13,000 \mathrm{rpm}$ for $15 \mathrm{~min}$ in an Eppendorf centrifuge and the protein concentration of the supernatant was determined using the BCA protein assay kit as described in the protocol supplied by the manufacturer. The same amount of soluble protein from each lysate was analyzed by SDS-PAGE $(12 \%)$. Proteins were then transferred electrophoretically onto Immobilon $\mathrm{P}$ membranes. The blots were blocked by incubating with $5 \%$ nonfat dry milk in Tris-buffered saline containing $0.1 \%$ Tween 20 (TTBS) for $1 \mathrm{hr}$ at room temperature. The blots were then incubated with polyclonal anti-phosphotyrosine antibodies $(1: 1000)$ in the blocking solution overnight. The blots were washed three times with TTBS and further incubated for $30 \mathrm{~min}$ with horseradish peroxidase-conjugated anti-rabbit lgGs (1:5000). After washing with TTBS, the blots were visualized using an ECL detection system as described in the manufacturers protocol.

\section{In Gel ERK Assay}

Cells were treated as described in the figure legend and lysed with $2 \mathrm{ml}$ of lysis buffer containing $50 \mathrm{mM}$ Tris$\mathrm{HCl}, \mathrm{pH}$ 7.5, $150 \mathrm{mM} \mathrm{NaCl}, 2 \mathrm{mM}$ EDTA, 1 mM EGTA, $1 \mathrm{mM} \mathrm{Na} \mathrm{VO}_{4}, 10 \mathrm{mM} \mathrm{NaF}, 1 \mathrm{mM}$ DTT, $1 \mathrm{mM}$ PMSF, $25 \mu \mathrm{g} / \mathrm{ml}$ leupeptin, $25 \mu \mathrm{g} / \mathrm{ml}$ aprotinin, $5 \mathrm{mM}$ benzamidine, $1 \%$ Triton $X-100,5 \%$ glycerol for $30 \mathrm{~min}$. The ERK activity was assayed by a modification of in-gel 
kinase assay described by Hibi et al. (1993). The clear lysates were prepared by spinning in an Eppendorf centrifuge at $14,000 \mathrm{rpm}$ for $15 \mathrm{~min}$. The lysates boiled in equal volume of $2 x$ SDS sample buffer for $5 \mathrm{~min}$ and separated on a $10 \%$ polyacrylamide gel containing $0.25 \mathrm{mg} / \mathrm{ml} \mathrm{MBP}$. ERKs on the gel was renatured by incubating the gel sequencially with buffer $\mathrm{A}(20 \% 2$ propanol in $50 \mathrm{mM}$ Tris- $\mathrm{HCl}, \mathrm{pH} 8.0), \mathrm{B}(5 \mathrm{mM}$ 2mercaptoethanol in $50 \mathrm{mM}$ Tris- $\mathrm{HCl}, \mathrm{pH} 8.0), \mathrm{C}(286.6$ $\mathrm{g} / 500 \mathrm{ml}$ guanidine- $\mathrm{HCl}, 5 \mathrm{mM}$ 2-mercaptoethanol in 50 $\mathrm{mM}$ Tris- $\mathrm{HCl}, \mathrm{pH} 8.0)$, and $\mathrm{D}(0.05 \%$ Tween 20 and 5 $\mathrm{mM}$ 2-mercaptoethanol in $50 \mathrm{mM}$ Tris- $\mathrm{HCl}, \mathrm{pH}$ 8.0) on a rocker at RT. Each buffer was included for $30 \mathrm{~min}$ twice. The gel was finally preincubated with $25 \mathrm{mM}$ kinase reaction buffer containing $40 \mathrm{mM} \mathrm{HEPES} / \mathrm{KOH}, \mathrm{pH}$ 8.0, $100 \mu \mathrm{M}$ EGTA, $5 \mathrm{mM} \mathrm{MgCl}_{2}$, and $2 \mathrm{mM}$ DTT for $30 \mathrm{~min}$ at $\mathrm{RT}$. The kinase reaction in the gel was performed by incubation with hot $(50 \mu \mathrm{Ci})$ and cold $(10 \mathrm{mM})$ ATP for $1 \mathrm{~h}$ at RT and terminated by washing them with a washing buffer (5\% TCA, 1\% Na-pyrophosphate). The gel was washed until the radioactivity was reduced down to the background level. The phosphorylated MBP on the dried gel was visualized by autoradiography.

\section{Measurement of JNK Activity}

The JNK proteins are activated by dual phosphorylation at a Thr-Pro-Tyr motif. We examined the increase of phosphorylated JNK as an indication of JNK activation by SDS-PAGE and Western blot analysis against anti phospho-JNK (G-7). The JNK activity was also assayed by a modification of in vitro c-Jun kinase assay on agarose beads described by Hibi et al. (1993). The cells were lysed in $2 \mathrm{ml}$ of lysis buffer $(50 \mathrm{mM}$ Tris- $\mathrm{HCl}, \mathrm{pH}$ 7.5, containing $150 \mathrm{mM} \mathrm{NaCl}, 2 \mathrm{mM}$ EDTA, 1 mM EGTA, $1 \mathrm{mM} \mathrm{Na}_{3} \mathrm{VO}_{4}, 10 \mathrm{mM} \mathrm{NaF}, 1 \mathrm{mM}$ DTT, $1 \mathrm{mM}$ PMSF, $25 \mu \mathrm{g} / \mathrm{ml}$ leupeptin, $25 \mu \mathrm{g} / \mathrm{ml}$ aprotinin, $5 \mathrm{mM}$ benzamidine, $1 \%$ Triton X-100, 10\% glycerol). Cell lysates were incubated with c-Jun (1-169) GST-agarose conjugate $\left(2 \mu \mathrm{g}\right.$ c-Jun protein in $20 \mathrm{I}$ suspension) at $4^{\circ} \mathrm{C}$ for 1 hour and the beads were washed twice with a lysis buffer and twice with a basic buffer for kinase assay containing $20 \mathrm{mM}$ Tris-HCl, pH 7.5, $2 \mathrm{mM}$ DTT, and 20 $\mathrm{mM} \mathrm{MgCl}$. The beads were incubated with hot and cold ATP mix ( $25 \mu \mathrm{M}$ ATP and $5 \mu \mathrm{Ci} \gamma^{32} \mathrm{P}$ ATP) in $50 \mu \mathrm{l}$ of basic kinase assay buffer for $10 \mathrm{~min}$ at $30^{\circ} \mathrm{C}$. Adding $2 \times$ SDS sample buffer and subsequent boiling in a water bath stopped the reaction. The phosphorylated c-Jun was separated on $10 \%$ polyacrylamide gel by SDSPAGE and the dried gel was analyzed by autoradiography.

\section{Results}

Ethanol inhibits the growth of Swiss 3T3 fibroblasts
In order to study the molecular mechanisms of the ethanol effect on cell growth, a well characterized cell line, Swiss 3T3 fibroblasts was selected. The cells have been extensively studied for the cellular responses against serum containing various mitogens. The cells are quiescent by serum starvation and reinitiate to enter the cell cycle by adding the serum or individual mitogens including platelet-derived growth factor (PDGF) and epidermal growth factor (EGF). The potency of ethanol effect on cell growth is known to vary according to tissues and cells. The initial effect of ethanol on cell growth was monitored by measuring the amount of viable cells by MTT assay or counting the number of cells. After 3 days' incubation of cells with various concentration of ethanol, viable cells were reduced dose-dependently in ethanol-treated cells (Figure 1A). There was no visible cytotoxic effect to induce cell death at the concentration range of $50-300 \mathrm{mM}$ ethanol, and most of following study was done within this range of ethanol concentration.

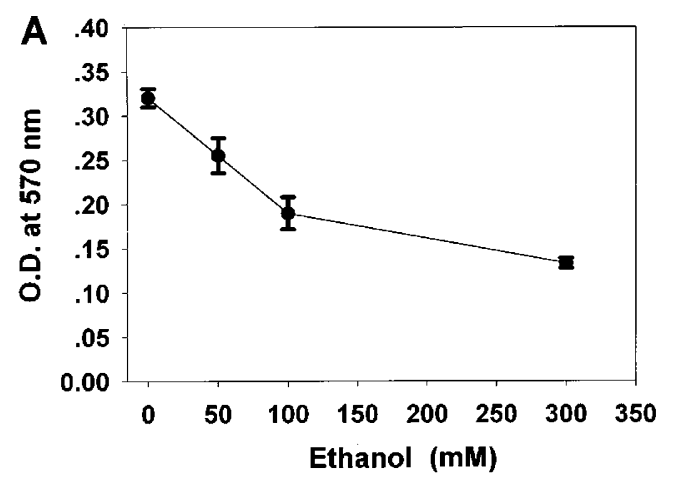

B

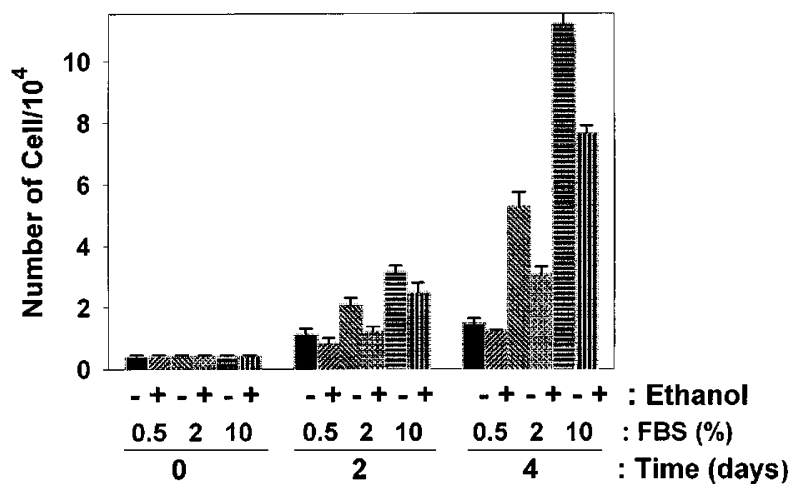

Figure 1. Effect of ethanol on the growth of Swiss 3 T3 fibroblasts. A. Swiss 3T3 fibroblasts were grown on 24-well plates in the culture medium containing $10 \%$ FBS for 1 day and the medium was changed to the culture medium with various concentration of ethanol. After 3 days' incubation, the viability of cells was examined by MTT assay. B. The culture medium for the cells grown on 24 well plates were treated various amount of FBS $(0.5,2$, or $10 \%)$ in the absence (-) or presence (+) of $100 \mathrm{mM}$ ethanol. The number of cells was counted at 2 and 4 days after ethanol treatment using a cell counting chamber. Each data represents a mean and standard error. The experiment repeated twice and the results were similar. 
The ethanol effect upon the various levels of FBS was examined by adding $100 \mathrm{mM}$ ethanol to cells growing in the culture medium containing $0.5,2$, or $10 \%$ of FBS and counted the number of cells after 2 and 4 days' incubation (Figure 1B). Cells did not grow well in the culture medium containing $0.5 \%$ FBS. In this case, the ethanol effect was not significant. The cell growth increased by the addition of $2 \%$ FBS, but ethanol reduced it to $40-50 \%$ of the level observed in the ethanol-untreated control. When the same amount of ethanol was added to the culture medium including $10 \%$ FBS, a lower rate of reduction, that is, only $20-30 \%$ reduction of cell growth was observed. Cells seem to overcome the inhibitory effect of ethanol by the higher concentration of serum. Our data demonstrates that ethanol exerts a differential effect on serum-induced cell growth depending on the concentration of serum.

\section{Ethanol inhibits growth factor-induced DNA synthe- sis}

EGF and PDGF are selected as representitive mitogens for the Swiss 3T3 fibroblasts and the ethanol effect was examined by DNA synthesis post growth factor treatment of cells. DNA synthesis was examined by measuring the $\left[{ }^{3} \mathrm{H}\right]$ thymidine incorporation to the serum-starved, quiescent cells at $16 \mathrm{~h}$ after the addition of the growth factors. The incorporation of $\left[{ }^{3} \mathrm{H}\right]$ thymidine into DNA increased with increasing concentration of EGF (Figure 2A) or PDGF (Figure 2B). Maximal stimulation of $\left[{ }^{3} \mathrm{H}\right]$ thymidine incorporation occurred in the presence of $50 \mathrm{nM}$ EGF or 25 $\mathrm{ng} / \mathrm{ml}$ of PDGF. At the higher concentration of EGF than $50 \mathrm{nM}$ or PDGF than $25 \mathrm{ng} / \mathrm{ml}$, decreased incorporation of $\left[{ }^{3} \mathrm{H}\right]$ thymidine was seen. Decreasing $\left[{ }^{3} \mathrm{H}\right]$ thymidine incorporation at the higher concentration of EGF was much more dramatic. The inhibitory effect of high concentration of EGF was also shown in HF cells (Carpenter and Cohen, 1976) and in A431 cells (Kawamoto et al., 1983). The addition of high concentration of EGF induces sustained expression of a CDK inhibitor p21waf1/cip1, which might be an important mediator of EGF-induced G1 arrest and growth inhibition (Fan et al., 1995). As shown in Figure 2A, EGF-induced DNA synthesis was dramatically reduced in the presence of ethanol. There was a reduction of net increase in $\left[{ }^{3} \mathrm{H}\right]$ thymidine incorporation: $68 \%$ at $1 \mathrm{nM}, 63 \%$ at $10 \mathrm{nM}, 87 \%$ at $50 \mathrm{nM}$, and $77 \%$ at $100 \mathrm{nM}$ of EGF. Ethanol exerted less effect on PDGF-induced DNA synthesis (Figure 2B). About 20$30 \%$ reduction of net increase was observed.

\section{Ethanol inhibits growth factor-induced protein tyro- sine phosphorylation}

EGF- and PDGF-activated signal transduction pathways upon ethanol treatment was investigated. Both EGF and PDGF elicit many cellular responses via activation of intrinsic tyrosine kinase in their corresponding receptors.

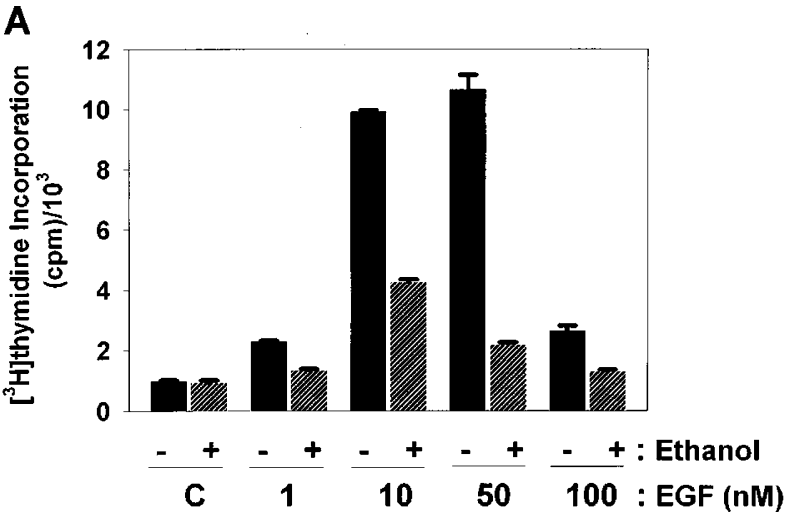

B

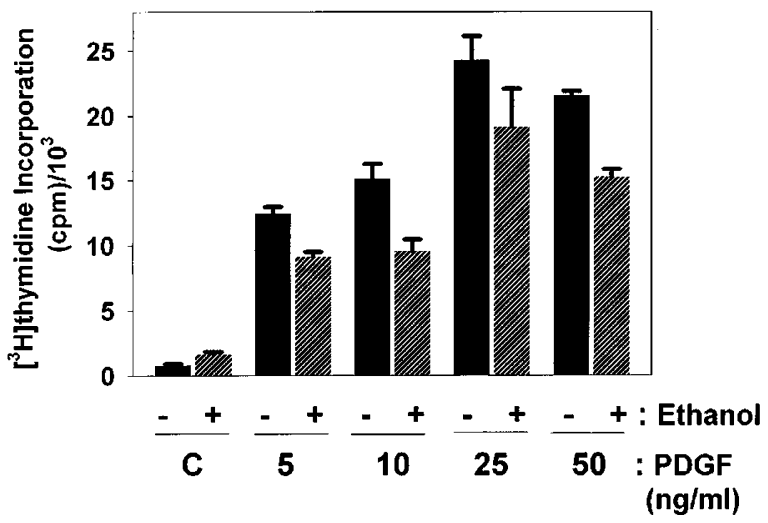

Figure 2. Effect of ethanol on EGF- and PDGF-induced DNA synthesis in Swiss 3T3 fibroblasts. Swiss 3T3 cells grown for 2 days in 6 well plates were serum-starved for 2 days by incubation with serum free medium. Cells were stimulated by adding various concentrations of EGF (A) or PDGF (B) for 16 hours. One half $\mu \mathrm{Ci} / \mathrm{ml}$ of $\left[{ }^{3} \mathrm{H}\right]$ thymidine was then added to label the cells for $4 \mathrm{~h}$. DNA was extracted and the radioactivity incorporated into DNA was counted as described in Materials and Methods. The data represents an average of 3 values of count as cpm.

Subsequent tyrosine phosphorylation of the receptors and many other cellular proteins induces mitogenic signals. In order to test if ethanol affects the initial event, we examined its effect on tyrosine phosphorylation of cellular proteins including the receptors. Tyrosine phosphorylated proteins were visualized by SDS-PAGE and Western blot analysis against polyclonal anti-phosphotyrosine antibodies. The presence of tyrosine-phosphorylated proteins of $178-185,120,100,85,53 \mathrm{kD}$ was detected in EGF- or PDGF-stimulated cells. The tyrosine-phosphorylated 178 and $185 \mathrm{kD}$ proteins might be the activated EGF and PDGF receptor, respectively. Ethanol diminished the level of tyrosine phosphorylation in cells treated with 1-10 nM of EGF (Figure $3 \mathrm{~A}$ ) or $1-10 \mathrm{ng} / \mathrm{ml}$ of PDGF (Figure 3B). When the higher concentrations of EGF (100 nM) or PDGF (50 ng/ml) were added to the medium, the ethanol effect was reduced.

To characterize further whether ethanol exerts its effect by modulating the receptor binding of the growth factors or by intracellular metabolites, the cells were preincubat- 
A

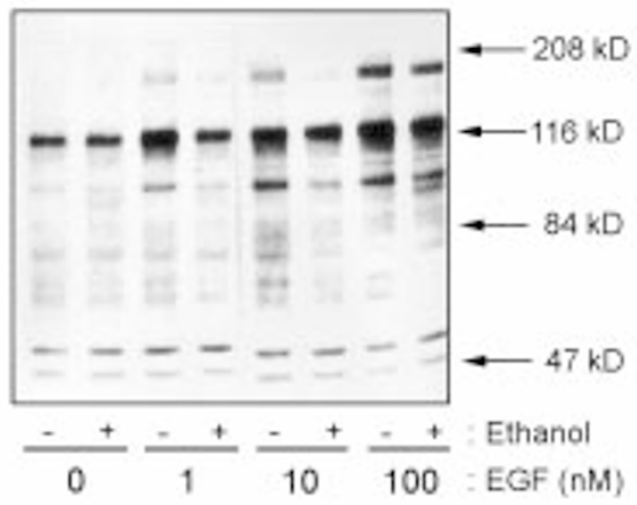

B

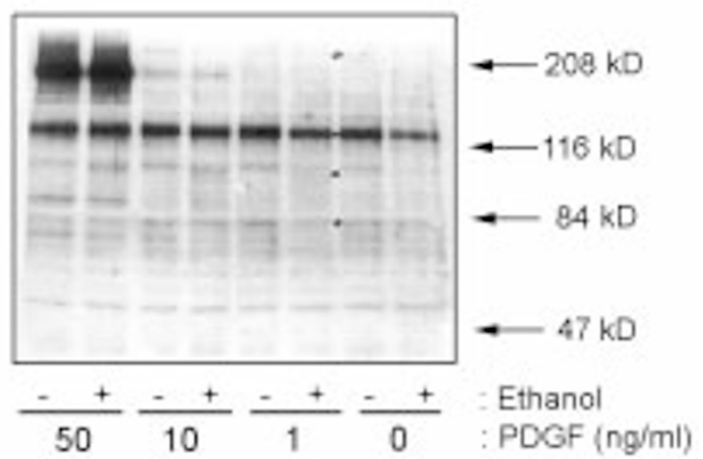

C

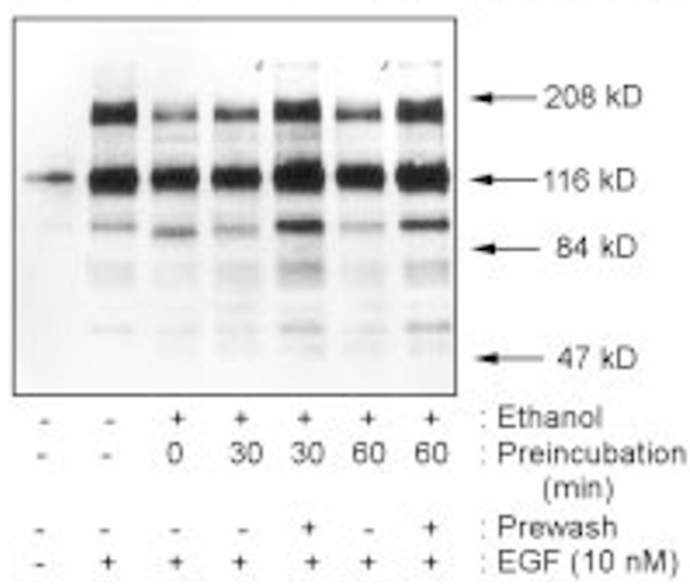

Figure 3. Effect of ethanol on EGF- and PDGF-induced activation of protein tyrosine phosphorylation. Cells were serum-starved for 1 day and treated with various density of EGF $(\mathbf{A})$ or PDGF $(\mathbf{B})$ in the absence $(-)$ or in the presence $(+)$ of $100 \mathrm{mM}$ ethanol. The quescent cells were preincubated with $100 \mathrm{mM}$ ethanol for 0-60 min (C). After then, cells were PBS-washed to remove extracellular ethanol (prewash + ) and the cells were treated with 10 nM of EGF. Cells were lysed at 5 min after the treatment with the growth factor and the tyrosine phosphorylated proteins were visualized by SDSPAGE and Western blot analysis using polyclonal anti-phosphotyrosine antibodies.

ed with ethanol for 30-60 min and then ethanol was washed out. EGF treatment for 5 min induced cellular tyrosine phosphorylation in ethanol-pretreated and washed cells similar to that in the untreated cells (Figure 3C). Once ethanol was removed, its inhibitory effect disappeared. Such result indicates that ethanol should be
A

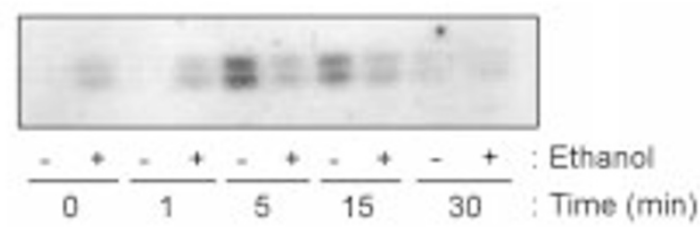

B

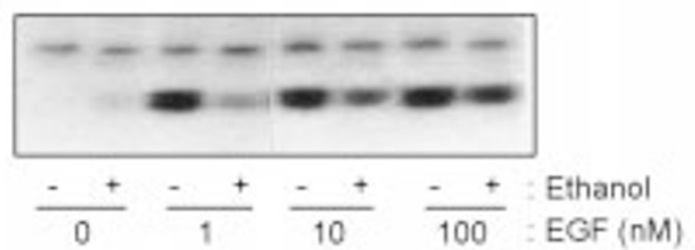

C

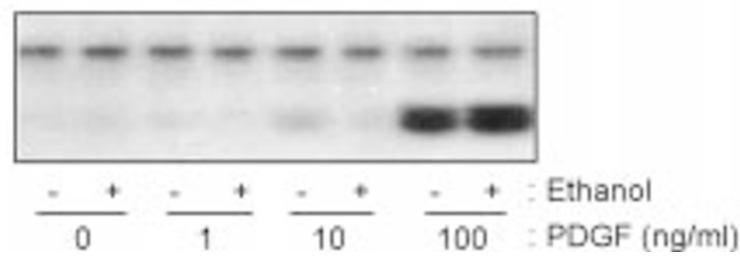

Figure 4. Effect of ethanol on the growth factor-induced ERK activation. A. Cells were serum-starved for 1 day and lysed at the indicated time after the treatment with $10 \mathrm{nM}$ EGF in the absence $(-)$ or presence $(+)$ of $100 \mathrm{mM}$ ethanol. B. The serum-starved cells were treated with various concentration of EGF in the absence or presence of $100 \mathrm{mM}$ ethanol and lysed after 5 $\min$. C. The serum-starved cells were treated with various concentration of PDGF in the absence or presence of $100 \mathrm{mM}$ ethanol and lysed after $5 \mathrm{~min}$. ERKs activation was measured in the cell lysates by in-gel kinase assay as described in "Materials and Methods".

present in the medium when cells were treated with the growth factors in order to affect the cellular signaling events.

\section{Ethanol modulates the growth factor-induced MAPK activity}

Mitogen-activated protein kinases (MAPKs) are involved in the integration of multiple signaling pathways leading to cellular responses. EGF and PDGF stimulated the two MAPKs, ERK and JNK, via ras signaling system. To investigate whether acute exposure to ethanol alters the MAPK activation, ERK activity were measured by in-gel ERK kinase assay and JNK activity by a solid bead assay using c-Jun GST-glutathione agarose conjugate. Ten $\mathrm{nM}$ of EGF stimulated ERK with a peak at $5 \mathrm{~min}$ (Figure 4A). After $15 \mathrm{~min}$, the ERK activity decreased slowly to the basal level during $30 \mathrm{~min}$. In the presence of 100-300 mM ethanol, basal level of ERK activity increased but ERK activation by EGF was completely blocked during the experimental period. In contrast to the results observed in the concentration range of 1-10 nM EGF, the addition of $100 \mathrm{nM}$ EGF relieved the ethanol effect (Figure 4B). Similar phenomenon was observed for the PDGF-induced ERK activation (Figure 4C).

EGF-stimulated JNK activity peaked at 5-10 min and returned to the basal level after 10 min slowly. In the 


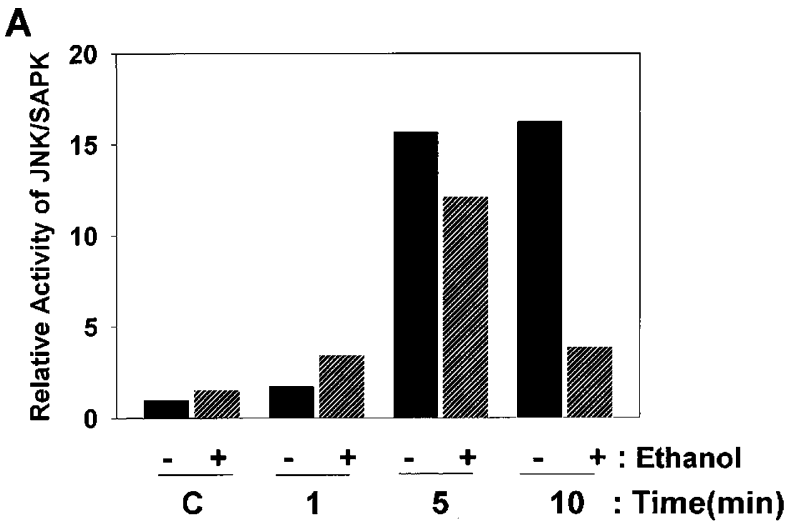

B

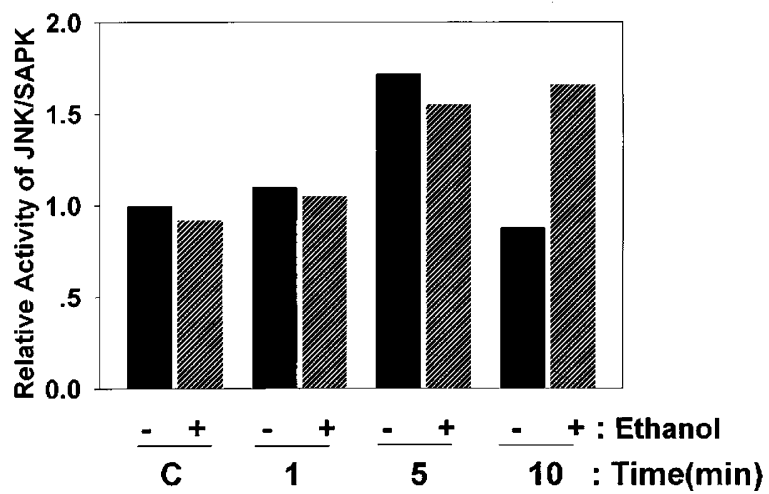

Figure 5. The growth factor-induced activation of JNK in ethanol-treated Swiss 3T3 fibroblasts. Cells were serum-starved for 1 day and lysed at 1, 5, and $10 \mathrm{~min}$ after the treatment with $10 \mathrm{nM} \mathrm{EGF}(\mathbf{A})$ or $10 \mathrm{ng} / \mathrm{ml}$ of PDGF (B) in the absence or presence of $100 \mathrm{mM}$ ethanol. The activity of SAPK/ JNK was determined using in vitro bead assay as described in "Materials and Methods". The phosphorylated c-Jun protein was separated by SDSPAGE $(8 \%)$ and the dried gel was analyzed by autoradiography.

presence of ethanol, the EGF-stimulated JNK activity was reduced slightly at $5 \mathrm{~min}$ and returned to the basal level earlier than the control (Figure 5A). PDGF-induced JNK activation was transient with peak at $5 \mathrm{~min}$. At 10 $\mathrm{min}$, the activity returned to the basal level. Interestingly, there was a delayed increase in PDGF-induced JNK activity in the presence of ethanol (Figure 5B). The result tends to suggest that the signaling pathway to activate JNK by EGF and PDGF would be different.

\section{Discussion}

Many studies have demonstrated the direct effect of ethanol on growth factor-stimulated cell proliferation. Ethanol interfered the proliferation of IGF-1-stimulated Balb/c 3T3 cells (Resnicoff et al., 1993) and rat glioblastoma cells (Resnicoff et al., 1994), muscarinic receptorstimulated glial cells (Guizzetti and Costa, 1996), bFGFand PDGF-induced neuroblastoma cells (Luo and Miller, 1997b), and PDGF-stimulated astrocyte (Luo and Miller, 1999). However, ethanol does not always modulate the action of all growth factors. Some growth factors are targets of ethanol toxicity but the others are not (Higashi and Hoek, 1991; Luo and Miller, 1997a). Pretreatment of the cells with sublethal concentrations of ethanol markedly inhibited a subsequent stimulation of phospholipase $C$ by vasopressin, angiotensin II, or epidermal growth factor in isolated rat hepatocytes. By contrast, the effects of the alpha 1-adrenergic agonist phenylephrine and of glucagon were not affected by ethanol pretreatment (Higashi and Hoek, 1991). Moreover, ethanol exerts differential effect on the same growth factor depending on the cell type. Although ethanol inhibits the signaling events by EGF in hepatocytes (Higashi and Hoek, 1991; Saso et al., 1997; Zhang and Farrell, 1999), ethanol did not directly interfere with EGF receptor function in mouse BALB/c3T3 cells (Resnicoff et al., 1996). Ethanol inhibited the proliferation of PDGF-stimulated astrocyte, but some studies could not show the inhibitory effect of ethanol on PDGF-induced increases in cell proliferation (Resnicoff et al., 1994; Guizetti and Costa, 1996) and in DNA synthesis (Tomono and Kiss, 1995; DeVito et al., 1997). The discrepancies among those reports might be due to the potency of the growth factor and ethanol on each cell line. In the present study, we provide evidence that ethanol directly affects both cell growth and growth factor-induced cellular signaling in Swiss 3T3 cells. DNA synthesis and protein tyrosine phosphorylation induced by EGF was seriously distorted by ethanol. The effect of ethanol on PDGF-induced response was weak but concentration-response experiment clearly demonstrated the inhibitory effect of ethanol on PDGF-induced cell proliferation, DNA synthesis and ERK activation. Differential susceptibility of cells to ethanol might correlate with their response to mitogenic growth factors (Luo and Miller, 1997a).

Free radical damage to cell membrane receptors may not be an important mechanism of alcohol-induced inhibition of cell proliferation. Previously, experiments with acetaldehyde and with the alcohol dehydrogenase inhibitor 4-methylpyrazole suggested that the inhibitory effect was due to ethanol itself and not to its metabolite acetaldehyde (Guizzetti and Costa, 1996). Alleviation of cellular radical production alone was not sufficient to prevent the abnormality in fetal rat hepatocyte function (Devi et al., 1993). When ethanol was pretreated for 1 hour and removed by PBS-washing, there were no changes in the growth factor-induced signaling pathways. Taken together, it can be concluded that ethanol should be present with growth factors at the same time to exert any effect on the signaling events.

Our data thus showed that the addition of excess amount of growth factors reduced the inhibitory effect of ethanol and is agreeable with the report by Higashi and Hoek (1991) demonstrating that ethanol effects were pronounced at low concentrations of agonists but they were not significant at saturating levels in hepatocytes. 
Studies using buccal mucosa and rat gastric mucosa demonstrated the reduction in the EGF receptor binding by ethanol (Wang et al., 1992, 1994). Chronic ethanol feeding causes a time-dependent reduction of the EGF binding to the receptor in rat stomach due to the reduction of EGF receptor number, and/or the affinity of the high-affinity binding site (Wang et al., 1996, 1997). In hepatocytes isolated from chronic ethanol-fed rats, binding to both high and low affinity states of the hepatic epidermal growth factor receptor was decreased by 40 $50 \%$ (O'Rourke et al., 1997). It might cause a concomitant decrease in the ability of the receptor tyrosine kinase to phosphorylate tyrosine residues. It raises the question of what causes the alteration of the affinity of growth factor to the receptor. There is a possibility that EGF receptor is damaged by ethanol-induced free radical as shown in the case of glucagon receptor (Shaw et al., 1995). Otherwise, the membrane environment could be altered to reduce the interaction between the growth factor and receptor. Ethanol induced activation of phospholipases $C$ and $D$ could metabolize the membrane lipids and rapidly produce unusual lipids such as phosphatidylethanol (Alling et al., 1984; Gustavsson et al., 1991). A lack of mitogenic product of phospholipases including phosphatidic acid might be one of the mechanisms that contributes to the inhibition of cell growth by ethanol (Kotter and Klein, 1999).

Ethanol itself activates some of signaling molecules but it blocks or potentiates their induction by other stimulants such as growth factors and hormones. Ethanol itself activates PLC (Rubin and Hoek, 1988; Rooney et al., 1989) whose product, diacylglycerol, in turn activates protein kinase $\mathrm{C}$, which desensitizes agonist-induced activation of PLC (Higashi and Hoek, 1991). Treatment of hepatocytes with $50 \mathrm{mM}$ ethanol elevated the basal activity of p42 ERK (Thombes et al., 1998). In this study, we also observed an elevation of basal ERK activity by 10 min incubation with $100 \mathrm{mM}$ ethanol. Ethanol might activate those signaling proteins by a pertussis toxinsensitive G-protein-dependent mechanism (Reddy and Shukla, 1996). In most cases, ethanol inhibits growth factor-induced receptor tyrosine autophosphorylation (Thurston, Jr. and Shukla, 1992; Resnicoff et al., 1993, 1994; Bhavani et al., 1995), which subsequently interferes with the activation of key down stream signaling mediators including PLC-g1 (Higashi and Hoek, 1991; Thurston, Jr. and Shukla, 1992; Saso et al., 1997; Zhang and Farrell, 1999), IRS-1 (Resnicoff et al., 1994; Bhavani et al., 1995), phosphatidylinositol-3 kinase (Resnicoff et al., 1994), and MAP kinases (Banerjee et al., 1998; Thombes et al., 1998; Seiler et al., 2000), and transcription factors such as c-myc, c-fos, and c-jun (Resnicoff et al., 1993). We also observed an inhibition of EGF- or PDGF-stimulated ERK activity.

It is not always true that the adverse effects of ethanol are mediated by inhibition of tyrosyl phosphorylation of some signaling molecules including the growth factor receptor. Although long-term ethanol feeding suppresses EGF-induced receptor autophosphorylation in rat hepatocytes, it shows a differential in the inhibition of downstream signaling processes mediated by PLC, Shc, and Grb2 (Saso et al., 1997). In FOCUS hepatocellular carcinoma cells, which overexpress IRS-1, ethanol treatment substantially inhibits IRS-1 and MAP kinase signaling and growth-associated gene expression, but has no effect on Shc phosphorylation, which activates p21ras through an IRS-1 independent pathway (Banerjee et al., 1998). Ethanol inhibited PDGF-BB-mediated phosphorylation of PDGFRa, but it had little effect on PDGFRb autophosphorylation. Likewise, ethanol abolished the association of PDGFa to Ras GTPase-activating protein (Ras-GAP), but it did not affect the binding of Ras-GAP to PDGFb. PDGF stimulated the activities of mitogenactivated protein kinase (MAPK) in protein kinase $C$ (PKC) independent and dependent manners. Ethanol inhibited the PKC-independent, acute activation of MAPK; however, it stimulated the PKC-dependent, sustained activation of MAPK (Luo and Miller, 1999). Ethanol enhances NGF- and bFGF-stimulated neurite outgrowth in PC12 cells by stimulating phosphorylation and activation of MAP kinases through a delta or epsilon PKC-regulated pathway (Roivainen et al., 1995; Pandy, 1996). In our study, ERK activation within 10 min incubation with PDGF or EGF might implicate the ERK activation via PKC-independent pathway.

We demonstrated that ethanol exerts a potential inhibitory effect on JNK activation by EGF. However, it rather stimulated PDGF-induced JNK activation at 10 min. The differential effect of EGF and PDGF on JNK seems to suggest that the JNK activation pathway would be different in the two growth factors. Subsequent autophosphorylation of the receptors or their phosphorylation by receptor-associated protein kinases has been speculated to induce the activation of MAPK cascade including ERK and JNK (Pomerance et al., 1998). It was suggested that the dynamic balance between ERK and JNKs or p38 and the duration of MAPK activation would be important in determining the final cellular fate (Xia et al., 1995; Marshall, 1995; Chen et al., 1996; Kang et al., 1999). Differential effect of ethanol on the growth factorstimulated ERK and JNK might be another determinant for the final effect of ethanol on cell proliferation.

The effect of ethanol varied according to its concentration and also the incubation time with ethanol. EGFinduced tyrosine phosphorylation of PLC- $\gamma 1$, a substrate for EGF receptor tyrosine kinase, in intact A431 cells showed a biphasic pattern (Thurston, Jr. and Shukla, 1992). In the presence of low concentration of ethanol, EGF-stimulated tyrosine kinase was potentiated. However, at higher concentrations of ethanol, a decrease was observed. Acute exposure to ethanol $(0-400 \mathrm{mM})$ for 1 hr had no effect on either basal or serum- and phorbol- 
12-myristate-13-acetate (PMA)-stimulated ERK activity in a normal mouse embryonic liver cell line, BNLCL2 (Reddy and Shukla, 1996). Exposure to ethanol for 16$24 \mathrm{~h}$ prolongs or potentiates the activation of ERK induced by various agonists in a normal mouse embryonic liver cell line (Reddy and Shukla, 1996) and in primary rat hepatocytes (Chen et al., 1998). Exposure to ethanol for $16 \mathrm{~h}$ increased the basal JNK activity but there was no change in agonist-induced JNK activation. Whereas chronic ethanol intake for 60 days inhibited the activation of ERK, p38, and JNK induced either by partial hepatectomy or by treatment with various agonists (Zeldin et al., 1996; Chen et al., 1998). In the present study, we observed that acute ethanol treatment for 510 min inhibited growth factor-stimulated tyrosine phosphorylation and ERK activation even in the absence of any preincubation with ethanol. Taken together, these observations seem to provide the molecular mechanism of acute ethanol treatment on cell growth.

\section{Acknowledgements}

We would like to thank Yun-Jung Rho for her technical support.

\section{References}

Alling, C., Gustavsson, L., Mansson, J. E., Benthin, G. and Anggard, E. (1984) Phosphatidylethanol Formation in Rat Organs After Ethanol Treatment. Biochim. Biophys. Acta 793: 119-122

Arnon, R., Esposti, S. D. and Zern, M. (1995) Molecular biological aspects of alcohol-induced liver disease. Alcohol Clin. Exp. Res. 19: 247-256

Banerjee, K., Mohr, L., Wands, J. R. and de la Monte, S. M. (1998) Ethanol inhibition of insulin signaling in hepatocellular carcinoma cells. Alcohol Clin. Exp. Res. 22: 2093-2101

Bhavani, K., de la Monte, S., Brown, N. V., Xu, Y. Y., Sasaki, Y. and Wands, J. R. (1995) Effect of ethanol on p36 protein kinase substrate and insulin receptor substrate 1 expression and tyrosyl phosphorylation in human hepatocellular carcinoma cells. Alcohol Clin. Exp. Res. 19: 441-446

Carpenter, G. and Cohen, S. (1976) Epidermal growth factor and the proliferation of human fibroblasts. J. Cell Physiol. 88: 227-238

Carter, E. A. and Wands, J. R. (1985) Ethanol inhibits hormone stimulated hepatocyte DNA synthesis. Biochem. Biophys. Res. Commun. 128: 767-774

Chen, J., Ishac, E. J. N., Dent, P., Kunos, G. and Gau, B. (1998) Effects of ethanol on mitogen-activated protein kinase and stress-activated protein kinase cascades in normal and regenerating liver. Biochem. J. 334: 669-676

Chen, J. P., Bao, H. F., Sawyer, S., Kunos, G. and Gao, B.
(1997) Effects of short and long term ethanol on the activation of signal transducer and activator transcription factor 3 in normal and regenerating liver. Biochem. Biophys. Res. Commun. 239: 666-669

Chen, Y. R., Meyer, C. F. and Tan, T. H. (1996) Persistent activation of c-Jun N-terminal kinase 1 (JNK1) in g radiationinduced apoptosis. J. Biol. Chem. 271: 631-634

DeVito, W. J., Stone, S. and Mori, K. (1997) Low concentrations of ethanol inhibits prolactin-induced mitogenesis and cytokine expression in cultured astrocytes. Endocrinology 138: $922-928$

Devi, B. G., Henderson, G. I., Frosto, T. A. and Schenker, S. (1993) Effect of ethanol on rat fetal hepatocytes: studies on cell replication, lipid peroxidation and glutathione. Hepatology 18: $648-659$

Fan, Z., Lu, Y., Wu, X., DeBlasio, A., Koff, A. and Mendelsohn, J. (1995) Prolonged induction of p21Cip1/WAF1/CDK2/PCNA complex by epidermal growth factor receptor activation mediates ligand-induced A431 cell growth inhibition. J. Cell. Biol. 131: $235-242$

Guizzetti, M. and Costa, L. G. (1996) Inhibition of muscarinic receptor-stimulated glial cell proliferation by ethanol. $J$ Neurochem 67: 2236-2245

Gustavsson, L., Moehren, G. and Hoek, J. B. (1991) Phosphatidylethanol Formation in Rat Hepatocytes. In Molecular and Cellular Mechanisms of Alcohol and Anesthetics. (Robin, E., Miller, K. W., Roth, S. H., eds) Ann. N.Y. Acad. Sci., Vol. 625 , pp. $438-440$

Hibi, M., Lin, A., Smeal, T., Minden, A. and Karin, M. (1993) Identification of an oncoprotein- and UV-responsive protein kinase that binds and potentiates the c-Jun activation domain. Genes Dev. 7: 2135-2148

Higashi, K. and Hoek, J. B. (1991) Ethanol causes desensitization of receptor-mediated phospholipase $\mathrm{C}$ activation in isolated hepatocytes. J. Biol. Chem. 266: 2178-2190

Hoek, J. B., Thomas, A. P., Rooney, T. A., Higashi, K. and Rubin, E. (1992) Ethanol and signal transduction in the liver. FASEB J. 6: 2386-2396

Kang, C.-D., Do, I.-R., Kim, K.-W., Ahn, B.-K., Kim, S.-H., Chung, B.-S., Jhun, B.-H. and Yoo, M.-A. (1999) Role of Ras/ ERK-dependent pathway in the erythroid differentiation of K562 cells. Exp. Mol. Med. 31: 76-82

Kawamoto, T., Sato, J. D., Le, A., Polikoff, J., Sato, G. H. and Mendelsohn, J. (1983) Growth stimulation of A431 cells by epidermal growth factor: identification of high-affinity receptors for epidermal growth factor by an anti-receptor monoclonal antibody. Proc. Natl. Acad. Sci. USA 80: 1337-1341

Kotter, K. and Klein, J. (1999) Ethanol inhibits astroglial cell proliferation by disruption of phospholipase D-mediated signaling. J. Neurochem. 73: 2517-2523

Lieber, C. S. (1994) Alcohol and the liver. Gastroenterology 106: $1085-1105$

Luo, J. and Miller, M. W. (1999) Platelet-derived growth factormediated signal transduction underlying astrocyte proliferation: site of ethanol action. J. Neurosci. 19: 10014-10025 
Luo, J. and Miller, M. W. (1997a) Differential sensitivity of human neuroblastoma cell lines to ethanol: correlations with their proliferative responses to mitogenic growth factors and expression of growth factor receptors. Alcohol Clin. Exp. Res. 21: $1186-1194$

Luo, J. and Miller, M. W. (1997b) Basic fibroblast growth factor- and platelet-derived growth factor-mediated cell proliferation in B104 neuroblastoma cells: effect of ethanol on cell cycle kinetics. Brain Res. 770: 139-150

Marshall, C. J. (1995) Specificity of receptor tyrosine kinase signaling: transient versus sustained extracellular signal-regulated kinase activation. Cell 80: 179-185

Miyakawa, T., Yagi, T., Kitazawa, H., Yasuda, M., Kawai, N., Tsuboi, K. and Niki, H. (1997) Fyn-kinase as a determinant of ethanol sensitivity: relation to NMDA-receptor function. Science 278: $698-701$

O'Rourke, M. F., Tuma, D. J. and Casey, C. A. (1997) Decreased binding and autophosphorylation of the epidermal growth factor receptor in ethanol-fed rats. Biochem. Pharmacol. 53: 1445-1450

Pandey, S. C. (1996) Protein kinase C: molecular and cellular targets for the action of ethanol. Alcohol Clin. Exp. Res. 20: $67 \mathrm{~A}-71 \mathrm{~A}$

Pomerance, M., Multon, M. C., Parker, F., Venot, C., Blondeau, J. P., Tacque, B. and Schweighoffer, F. (1998) Grb2 interaction with MEK-Kinase 1 is involved in regulation of Junkinase activities in response to epidermal growth factor. $J$. Biol. Chem. 273: 24301-24304

Reddy, M. A. and Shukla, S. D. (2000) Nuclear activation and translocation of mitogen-activated protein kinases modulated by ethanol in embryonic liver cells. Biochim. Biophys. Acta 1497: $271-278$

Reddy, M. A. and Shukla, S. D. (1996) Potentiation of mitogen-activated protein kinase by ethanol in embryonic liver cells. Biochem. Pharmacol. 51: 661-668

Resnicoff, M., Cui, S., Coppola, D., Hoek, J.B. and Rubin, R. (1996) Ethanol-induced inhibition of cell proliferation is modulated by insulin-like growth factor-I receptor levels. Alcohol Clin. Exp. Res. 20: 961-966

Resnicoff, M., Rubini, M., Baserga, R. and Rubin, R. (1994) Ethanol inhibits insulin-like growth factor-1-mediated signalling and proliferation of $\mathrm{C} 6$ rat glioblastoma cells. Lab. Invest. 71: 657-662

Resnicoff, M., Sell, C., Ambrose, D., Baserga, R. and Rubin, E. (1993) Ethanol inhibits the autophosphorylation of the insulin-like growth factor 1 (IGF-1) receptor and IGF-1-mediated proliferation of 3T3 cells. J. Biol. Chem. 268: 21777-21782

Roivainen, R., Hundle, B. and Messing, O. R. (1995) Ethanol enhances growth factor activation of mitogen-activated protein kinases by a protein kinase C-dependent mechanism. Proc. Natl. Acad. Sci. USA 92: 1891-1895

Rooney, T. A., Hager, R., Rubin, E. and Thomas, A. P. (1989) Short Chain Alcohols Activate Guanine Nucleotide-dependent Phosphoinositidase C in Turkey Erythrocyte Membranes. J. Biol. Chem. 264: 6817-6822
Rubin, R. and Hoek, J. B. (1988) Alcohol-induced Stimulation of Phospholipase C in Human Platelets Requires G-protein Activation. Biochem. J. 254: 147-153

Saso, K., Moehren, G., Higashi, K. and Hoek, J. B. (1997) Differential inhibition of epidermal growth factor signaling pathways in rat hepatocytes by long-term ethanol treatment. Gastroenterology 112: 2073-2088

Shaw, S., Eng, J. and Jayatilleke, E. (1995) Ethanol-induced free radical injury to the hepatocyte glucagon receptor. Alcohol 12: $273-277$

Seiler, A. E., Ross, B. N., Green, J. S. and Rubin, R. (2000) Differential effects of ethanol on insulin-like growth factor-I receptor signaling. Alcohol Clin. Exp. Res. 24: 140-148

Thurston, A. W., Jr. and Shukla, S. D. (1992) Ethanol modulates epidermal growth factor-stimulated tyrosine kinase and phosphorylation of PLC-gamma 1. Biochem. Biophys Res. Commun. 185: 1062-1068

Tombes, R. M., Auer, K. L., Mikkelsen, R., Valerie, K., Wymann, M. P., Marshall, C., McMahon, M. and Dent, P. (1998) The mitogen-activated protein (MAP) kinase cascade can either stimulate or inhibit DNA synthesis in primary cultures of rat hepatocytes depending upon whether its activation is acute/ phasic or chronic. Biochem. J. 330: 1451-1460

Tomono, M. and Kiss, Z. (1995) Ethanol enhances the stimulatory effects of insulin and insulin-like growth factor-1 on DNA synthesis in NIH ЗТ3 fibroblasts. Biochem. Biophys Res. Commun. 208: 63-67

Wang, S. L., Wu-Wang, C. Y., Feng, J., Espina, N. and Garro, A. J. (1996) Chronic ethanol feeding alters the structure and function of the epidermal growth factor receptor in rat stomach. Alcohol 13: 461-466

Wang, S. L., Feng, J. and Wu-Wang, C. Y. (1997) Timedependent alteration of epidermal growth factor receptor in rat stomach by ethanol feeding. Toxicol. Lett. 90: 115-123

Wang, S. L., Jacober, L., Wu-Wang, C. Y., Slomiany, A. and Slomiany, B. L. (1992) Ethanol-induced structural and functional alterations of epidermal growth factor receptor in buccal mucosa. Int. J. Biochem. 24: 85-90

Wang, S. L., Wu-Wang, C. Y., Slomiany, A. and Slomiany, B. L. (1994) Effect of acute ethanol treatment on epidermal growth factor receptor in the rat stomach. Alcohol 11: 11-15

Williams, R. J. and Kelly, E. (1993) Chronic Ethanol Reduces Imunologically Regulates Guanine Nucleotide-Binding Protein a Subunit Expression in NG108-15 Cells Independently of Extracellular Adenosine. Mol. Pharmacol. 43: 158-166

Xia, J., Dickens, M., Raingeaud, J., Davis, R. J. and Greenberg, M. E. (1995) Opposing effects of ERK and JNK-p38 MAP kinases on apoptosis. Science 270: 1326-1331

Zeldin, G., Yang, S. Q., Yin, M., Lin, H. Z., Rudra, R. and Diehl, A. M. (1996) Alcohol and cytokine-inducible transcription factors. Alcohol Clin. Exp. Res. 20: 1639-1645

Zhang, B. H. and Farrell, G. C. (1999) Chronic ethanol consumption disrupts complexation between EGF receptor and phospholipase C-gamma1: relevance to impaired hepatocyte proliferation. Biochem. Biophys. Res. Commun. 257: 89-94 